Katarzyna Karpińska-Szaj

Uniwersytet im. Adama Mickiewicza w Poznaniu

kataszaj@amu.edu.pl

\title{
PRZYGOTOWANIE DO PRACY Z UCZNIAMI O SPECJALNYCH POTRZEBACH EDUKACYJNYCH: JĘZYKOWE NARZĘDZIA DIAGNOSTYCZNE W PRAKTYCE NAUCZYCIELSKIEJ
}

\author{
Training for working with special needs students: \\ Language-based diagnostic instruments in teaching practice
}

Adapting foreign language teaching to the requirements of students with special educational needs requires prior diagnosis of the developmental potential of the pupils concerned. Because of the educational and rehabilitative character of foreign language learning in students with language and speech deficiencies, the diagnosis addresses the possibilities of using foreign language learning in developing general and linguistic competencies in both languages (native and foreign). The article presents the aims of diagnosing linguistic communicative competencies in the context of foreign language teaching. The differences between speech diagnosis and diagnosis performed for the needs of foreign language teaching are discussed, based on cases of pupils with deficiencies in their native language (Polish). The evaluation of the students' competencies involved reformulation as an instrument of linguistic diagnosis; learning strategies were also considered in the assessment.

Keywords: foreign languages teaching, students with special educational needs, language and speech deficiencies, language-based diagnostic instruments

Słowa kluczowe: nauczanie języków obcych, uczniowie ze specjalnymi potrzebami edukacyjnymi, deficyty języka i mowy, językowe narzędzia diagnostyczne 


\section{Uwagi wstępne}

Specjalne potrzeby edukacyjne nie implikują zmiany celu nauczania języka obcego (jest nim, jak dla wszystkich uczniów zdobycie umiejętności komunikowania się w języku obcym), wyznaczają jednak dobór technik pracy, kryteriów i sposobów oceniania postępów oraz udzielania odpowiedniego wsparcia w nauce. Warto też pamiętać, że sytuacja nauczania języków obcych stwarza dodatkowe korzyści wykraczające poza wymiar czysto edukacyjny. Nauka języka obcego dla uczniów ze specjalnymi potrzebami edukacyjnymi, zwłaszcza dla uczniów z niedoborami języka ojczystego może mieć wymiar terapeutyczny. Oprócz właściwych dla nauczanego przedmiotu dodatkowych (pozajęzykowych) korzyści poznawczych jak budowanie wiedzy o świecie, rozwijanie kompetencji kulturowej, kształtowanie postaw interkulturowych, działania dydaktyczne podejmowane na lekcji języka obcego mogą także sprzyjać rozwijaniu ogólnej kompetencji językowo-komunikacyjnej poprzez rozwijanie umiejętności uczenia się języków, kompensowanie deficytów pojęciowych i wzbogacanie środków językowych także w zakresie języka polskiego. Te ostatnie cele mogą zostać świadomie wpisane do indywidualnego programu nauczania języka obcego ${ }^{1}$ pod warunkiem skrojonego na miarę danego ucznia profilu jego potrzeb i możliwości uczenia się. Z tego powodu tak ważna jest odpowiednio postawiona diagnoza kompetencji językowych ucznia ze specjalnymi potrzebami edukacyjnymi nakierowana na naukę języka obcego, ale także na rozwijanie kompetencji w języku polskim².

Cele i metody pracy przewidziane w programie nauczania oraz zakres i kierunki działań terapeutycznych poprzez naukę języka obcego powinny być w każdej sytuacji specjalnych potrzeb edukacyjnych określane indywidualnie. Specyfika nauki języka obcego powoduje, że znajomość ogólnych zasad postępowania z uczniem ze specjalnymi potrzebami edukacyjnymi (zasady komunikacji, kryteria oceniania, dbałość o integrację w grupie rówieśniczej) jest cenna z punktu widzenia organizacji pracy w klasie, ale często niewystarczająca pod względem

\footnotetext{
${ }^{1}$ Indywidualny program edukacyjno-terapeutyczny (IPET) został wprowadzony jako obowiązkowa forma wsparcia edukacji i rehabilitacji uczniów z niepełnosprawnością posiadających orzeczenie o potrzebie nauczania specjalnego, uczniów niedostosowanych społecznie oraz zagrożonych niedostosowaniem społecznym na podstawie rozporządzeń Ministra Edukacji Narodowej z dnia 17 listopada 2010 r. (Dz. U. z 2010 r. nr 228 poz. 1487) oraz z dnia 30 kwietnia 2013 r. (Dz. U. z 2013 r., poz. 532).

${ }^{2}$ W sytuacji znacznego nasilenia zaburzeń rozwoju języka i mowy, nauka języka nie zawsze skutkuje wysokim opanowaniem kompetencji komunikacyjnej w nauczanym języku, jednak zawsze jest możliwe (choć także w różnym stopniu) rozwijanie ogólnych kompetencji uczenia się i tym samym poszerzanie kompetencji w języku ojczystym.
} 
kształcenia językowego obejmującego język obcy i jego kompensacyjne wartości przekładające się także na rozwój kompetencji w języku ojczystym. Aby poznać trudności ucznia ze specjalnymi potrzebami edukacyjnymi i określić kierunki rozwoju kompetencji komunikacyjnych w obu językach (czyli dokonać diagnozy dla rozwoju potencjału językowego dziecka) nauczyciel potrzebuje narzędzi, które spełniają kryteria jednocześnie edukacji i rehabilitacji językowej.

\section{Cele diagnozy potencjału językowego uczniów ze specjalnymi potrzebami edukacyjnymi w kontekście nauki języka obcego}

Kompetencje komunikacyjne, na które składają się zgodnie z Europejskim Opisem Kształcenia Językowego (ESOJK, 2003) kompetencje lingwistyczne (kompetencje leksykalna, gramatyczna, semantyczna, fonologiczna, ortoepiczna i ortograficzna), kompetencja socjolingwistyczna (znajomość relacji społecznych, konwencji wypowiedzi), kompetencja pragmatyczna i funkcjonalna (działania językowe w interakcjach społecznych) są odpowiednio uszczegółowione w nowej podstawie programowej nauczania języków obcych nowożytnych (2009). ESOKJ definiuje także kompetencje ogólne, wpływające na przebieg komunikacji: wiedzę deklaratywną, umiejętności praktyczne, uwarunkowania osobowościowe oraz umiejętność uczenia się (ibidem). Również i te składowe kompetencji ogólnych rozpisane są na kompetencje szczegółowe odpowiednio do kolejnych etapów nauczania. W sytuacji uczniów ze specjalnymi potrzebami edukacyjnymi, kompetencje te są szczególnie istotne, gdyż dotyczą samodzielnej pracy nad językiem, rozwijania umiejętności samooceny, współdziałania w grupie, rozwijania świadomości językowej oraz stosowania strategii komunikacyjnych i kompensacyjnych, a więc umiejętności szczególnie ważnych z punktu widzenia rehabilitacji języka i mowy.

Trudnością dydaktyczną jest z pewnością właściwy dobór odpowiednich technik i metod nauczania wynikających ze specjalnych potrzeb edukacyjnych konkretnego ucznia. Refleksja na ten temat powinna być poprzedzona doborem celów nauczania (odpowiednio do kompetencji językowych i ogólnych-kluczowych na danym etapie edukacyjnym dziecka), a ta z kolei właściwą diagnozą jego potencjału językowego. Takie współoddziaływanie komponentów kompetencji ogólnych i językowych wobec zmieniających się potrzeb ucznia jest podejściem integrującym wartości edukacyjne i rehabilitacyjne wynikające ze specjalnych potrzeb edukacyjnych (zob. Karpińska-Szaj, 2013: 93-97). Spełnia ono także zasadę indywidualizacji, która polega na właściwym oszacowaniu proporcji między składowymi danych kompetencji (zarówno językowymi, jak i ogólnymi) oraz potencjalnymi korzyściami terapeutycznymi, jakie są możliwe do osiągnięcia poprzez naukę języka obcego. 
W celu postawienia diagnozy i przygotowania indywidualnego programu nauczania języka obcego, nauczyciel ma do dyspozycji orzeczenie o potrzebie kształcenia specjalnego wydane przez poradnię psychologiczno-pedagogiczną. Nauczyciel może też zasięgnąć informacji od innych nauczycieli i terapeutów pracujących z uczniem, a także od rodziców/opiekunów dziecka. Informacje te są z pewnością przydatne do właściwej komunikacji z dzieckiem i wstępnego rozeznania specyfiki danego deficytu, nie zawsze jednak wystarczające dla właściwej (a więc przydatnej dla opracowania odpowiedniego programu nauczania języka obcego) diagnozy potencjału językowych kompetencji komunikacyjnych nakierowanych także na kompensowanie deficytów obserwowanych w języku ojczystym.

Poprzedzająca przyjęcie dziecka do szkoły oraz prowadzona w trakcie rehabilitacji językowej diagnoza logopedyczna stanowi podstawę odpowiedniego opracowania terapii specjalistycznej. Terapeuta powinien ustalić do jakich norm, umiejętności i kompetencji zmierza oraz jakimi metodami i środkami zamierza się posłużyć (zob. Gunia, 2006: 195). Poprzez rozpoznanie wady lub zaburzenia mowy uzyskanej na podstawie analizy stanu badanego ustala się indywidualnie dobrany tok postępowania terapeutycznego. Diagnoza logopedyczna wymaga zastosowania dwóch procedur: deskrypcji i interpretacji. Deskrypcja obejmuje badanie sprawności interakcyjnych: motoryki mowy, artykulacji, oceny środków językowych, struktur pojęciowych, realizację dialogu i realizację wypowiedzi narracyjnych. Interpretacja natomiast wymaga analizy wyników badań specjalistycznych, obejmuje wywiad z otoczeniem dziecka, rozpoznanie przypadku ${ }^{3}$. W badaniach logopedycznych wykorzystywane są różnorodne narzędzia: testy do badania mowy (ocena podsystemów języka: testy fonetyczne, słownikowe, gramatyczne), testy oceniające poziom rozumienia i produkcji mowy. Mają one charakter graficzny, werbalny i mieszany w zależności od etapu rozwojowego dziecka oraz specyfiki zaobserwowanego zaburzenia. Narzędzia te służą ocenie artykulacji (np. w celu wykrycia zaburzeń rozwoju mowy), sprawności językowej (np. wykorzystania kompetencji językowej w komunikacji) oraz badają słuch fonematyczny, kinestezję mowy (czucie ułożenia narządów mowy), płynność i prozodię mowy oraz słuch i pamięć słuchową. Istotne znaczenie mają też badania kompetencji pragmatycznej dziecka, które sprawdzają umiejętność dysponowania właściwymi dla danej osoby środkami komunikacji w określonej sytuacji społecznej. Badanie kompetencji pragmatycznej pozwala ustalić skuteczność sposobów wykorzystania zasobów językowych i strategii w działaniach komunikacyjnych, co umożliwia oszacowanie funkcjonowania językowego dziecka nie

\footnotetext{
${ }^{3}$ Procedury te są szczegółowo opisane w Czaplewka i Milewski, 2012.
} 
odnosząc go tylko do diagnozy medycznej danego przypadku. W ten sposób diagnoza logopedyczna staje się diagnozą pedagogiczną umożliwiającą dziecku indywidualny dobór wsparcia w rozwoju językowym ${ }^{4}$.

Diagnoza na potrzeby nauczania języków obcych może (a nawet powinna) wykorzystać dane uzyskane w badaniach logopedycznych, jednak jej cele wykraczają poza terapię logopedyczną i zasadzają się bardziej na wyłonieniu aspektów możliwych do edukacji i wspomagania rozwoju języka i mowy poprzez naukę języka obcego. Oznacza to, że w diagnozie na potrzeby nauczania języka obcego konieczne jest oszacowanie:

- potencjału kompetencji w języku polskim (te same trudności mogą bowiem wystąpić w trakcie przyswajania języka obcego, np. niewyraźna wymowa, braki leksykalne, błędy gramatyczne);

- potencjału komunikacyjnego czyli środków kompensujących deficyty pojęciowe i językowe używanych przez ucznia w celu zapewnienia obopólnego rozumienia (monitorowanie wypowiedzi, autokorekta, interakcja z nauczycielem i grupą);

- ewentualnych kierunków terapii językowej (rozwijanie strategii komunikacyjnych i strategii uczenia się);

- w konsekwencji ustalenie proporcji między kompetencjami językowymi a ogólnymi na danym etapie nauczania.

Diagnoza na potrzeby nauki języka obcego jest więc mniej specjalistyczna w znaczeniu oceny kompetencji dziecka i wyznaczenia kierunku terapii zaburzeń językowych. Prowadzi ona bardziej do nawiązania „kontraktu” uczenia się, który ma służyć celom kształcenia nakierowanego na rozwój kompetencji ogólnych i językowych w obu przyswajanych językach. Praktyczną wykładnią diagnozy w kontekście nauki języka obcego jest przygotowanie programu nauczania (IPETu). Wartością dla prognozowanych postępów w nauce jest powiązanie diagnozy ze strategią uczenia się języków (jest to diagnoza dla rozwoju językowych kompetencji komunikacyjnych w obu językach, polskim i obcym) oraz ułatwienie komunikacji z uczniem dzięki poznaniu jego trudności, a zarazem możliwości rozwojowych. Specyfika diagnozy na potrzeby nauczania języków obcych polega także na tym, że diagnozę tę sporządza nauczyciel filolog, posiadający przygotowanie metodyczne, ale nie będący specjalistą w dziedzinie zaburzeń języka i mowy. Pojawia się więc potrzeba narzędzi prostych, przydatnych w nauce języka obcego, mogących także stanowić element badania w działaniu ze względu na konieczność stałego dopasowywania

\footnotetext{
${ }^{4}$ Przykładem diagnozy pedagogicznej opierającej się na wieloetapowym (i wielokrotnym) badaniu kompetencji językowo-komunikacyjnych jest propozycja K. Krakowiak (2006) dotycząca osób z uszkodzeniami słuchu.
} 
technik nauczania i indywidualnej pomocy uczniowi ze specjalnymi potrzebami edukacyjnymi.

\section{Językowe narzędzia diagnostyczne: wykorzystanie przeformułowania}

Dzieci z niepełnosprawnością powodującą ograniczony dostęp do spontanicznego nabywania językowych kompetencji komunikacyjnych mają trudności z przyswojeniem utrwalonych w języku otoczenia sposobów interpretowania zjawisk rzeczywistości. W konsekwencji tych trudności zdarza się, że dziecko tworzy relacje niepoprawne lub/i fragmentaryczne, kojarząc przypadkowe cechy przedmiotów i na tej podstawie budując związki semantyczne i referencyjne. Rozpiętość i wyjątkowość tego typu trudności jest bardzo duża, gdyż zależy od rodzaju deficytu oraz od warunków towarzyszących rozwojowi dziecka: prowadzonej rehabilitacji, interakcji z otoczeniem, motywacji do nauki itd. Problemy językowe mogą dotyczyć jakości odbieranych i przekazywanych informacji (ich poprawności pod względem treści i formy, skuteczności komunikacyjnej) oraz sposobów tworzenia pojęć. Deficyty językowe są stosunkowo często identyfikowane w komunikacji z dzieckiem, co przekłada się na podejmowane działania rehabilitacyjne. Trudniejszym aspektem w rehabilitacji języka i mowy są trudności pojęciowe, gdyż są często niepowtarzalne. Stanowią one wprawdzie o cechach idiolektu dziecka, ale mogą pozostać niezauważone ze względu na nie zawsze rozpoznaną interpretację, jaką dziecko przypisuje danemu słowu/wyrażeniu.

Narzędziami umożliwiającymi oszacowanie tych trudności są obserwacje zachowań językowych polegające na gromadzeniu korpusów wypowiedzi pisemnych i ustnych, które stanowią dla nauczycieli języka polskiego i języków obcych podstawowe dane umożliwiające oszacowanie pojawiających się trudności językowych i uchwycenie postępów ucznia w toku nauczania, a w konsekwencji modyfikacji założeń IPETu. Zebrany korpus służy oszacowaniu kompetencji językowych, lecz nie przekłada się na bezpośrednią pracę z dzieckiem służącą rozwijaniu kompetencji uczenia się. Przykładem narzędzia umożliwiającym włączenie dziecka jako aktywnego partnera w (samo)ocenę i monitorowanie własnych postępów uczenia się języków są zadania językowe polegające na przeformułowaniu usłyszanej lub przeczytanej wypowiedzi.

Przeformułowanie jest narzędziem pozwalającym uchwycić deficyty pojęciowe oraz niedobory językowe. Odtworzenie tekstu źródłowego za pomocą środków językowych, którymi dysponuje uczeń pozwala przyjrzeć się powstałej produkcji pod kątem komunikacyjnej i reprezentatywnej funkcji języka. Ponadto, tworzenie narracji na podstawie tekstu źródłowego sprzyja obiektywizacji oceny danych językowych ze względu na możliwość odniesienia wypowiedzi dziecka do danych wyjściowych. 
Przygotowanie do pracy z uczniami o specjalnych potrzebach edukacyjnych...

Na funkcję komunikacyjną podczas przeformułowania składają się przede wszystkim dwa elementy:

- użyte środki językowe (zasoby leksykalne, poprawność gramatyczna i semantyczna, złożoność wypowiedzi) oraz

- strategie monitorowania wypowiedzi (przekazanie treści zrozumiałych dla odbiorcy).

Funkcja reprezentatywna w przeformułowaniach dzieci przejawia się głównie w sposobie prowadzenia narracji (np. poprzez uchwycenie i wyrażenie związków przyczynowo-skutkowych prowadzących do powiązania zdarzeń i świadczących o spójności wypowiedzi). W toku terapii obserwowana jest progresja: wyjście poza wyliczenie obiektów/postaci/wydarzeń, poprzez opis stanów emocjonalnych i działań bohaterów do interpretacji, wyjaśniania sytuacji. Jakość narracji zależy od potencjału poznawczego (zasobów pamięci, kierowania uwagą) i pozostaje $w$ ścisłym powiązaniu z repertuarem pojęciowym i językowym dziecka.

W perspektywie terapeutycznej przeformułowanie sprzyja także rozwijaniu kompetencji uczenia się, gdyż w stosowanej procedurze staje się strategią uczenia się o charakterze metapoznawczym. Przedrostek „meta” ${ }^{5}$ dotyczy uświadomienia sobie możliwości kompensowania niedoborów językowych, komunikacyjnych i pojęciowych poprzez systematyczne porównywanie obu języków (ojczystego i obcego) na poziomie ich opisu, użycia i myślowego funkcjonowania w nich. W przypadku uczniów z deficytami języka i mowy samo przeformułowanie nie stanie się automatycznie strategią uczenia się, jest nią dopiero w sytuacji nakierowana na kompensowanie trudności w dialogu z nauczycielem. Dialog dydaktyczny ma na celu odtworzenie procesów myślowych, które umożliwiły uchwycenie/budowanie znaczenia, co oznacza potrzebę rozwijania umiejętności heurystycznych ucznia, gdyż właśnie taka postawa „oświeconego obserwatora" własnych wypowiedzi na potrzeby uczenia się sprzyja edukacji i rehabilitacji. W dialogu dydaktycznym nauczyciel podąża „krok za uczniem". To właśnie w rozmowie z nim, poprzez obserwacje i odwoływanie się do jego kompetencji w języku polskim można nakierować uwagę ucznia na trudności, z których on sam nie zawsze zdaje sobie sprawę, lub przeciwnie, wycofuje się z komunikacji, gdyż ma przekonanie, że cokolwiek powie „i tak będzie źle" ${ }^{\prime \prime}$. Dialog dydaktyczny sprzyja też rozwijaniu postawy „poszukującej”: ważne

\footnotetext{
${ }^{5} \mathrm{Na}$ potrzeby niniejszego artykułu przyjęto klasyfikację ogólną strategii uczenia się przyznającą charakter „meta” tym strategiom, które zmierzają do wyłonienia, oceny i świadomego kontrolowania sposobów wypowiedzi (zob. Béguin, 2008).

${ }^{6}$ Przeformułowanie może się też stać strategią uczenia się, jeśli wykonanemu zadaniu towarzyszy kierowana (auto)refleksja nad wypowiedzią, a jej efektem w kontekście
} 
jest, by uczeń podjął wysiłek antycypowania znaczeń, poszukiwania możliwych rozwiązań (planowania i sprawowania kontroli nad swoją pracą umysłową). Przede wszystkim jednak dialog dydaktyczny podjęty po zadaniu polegającym na przeformułowaniu, może być wykorzystany w rozwijaniu strategii uczenia się i ich transferowaniu z jednego użycia językowego na inne (także w innym języku).

\section{Przykłady wypowiedzi dzieci: implikacje dla dydaktyki języka obcego}

W diagnozie językowych kompetencji uczniów ze specjalnymi potrzebami edukacyjnymi z wykorzystaniem przeformułowania posłużono się protokołem eksperymentalnym przygotowanym na potrzeby międzynarodowego projektu badawczego „Złożoność językowa w wieku 6 do 14 lat. Przyswajanie, produkcja wypowiedzi, przetwarzanie" ${ }^{\prime 7}$. Wybrane zadanie językowe polegające na przeformułowaniu tekstu źródłowego (zob. załącznik) przeczytanego przez nauczyciela wynika z przyjętego paradygmatu badawczego: hipotezy akwizycyjnej wywodzącej się z badań nad przekształcaniem wypowiedzi przez dzieci w fazie wczesnego przyswajania języka ojczystego. Zakłada się, że w zależności od wieku dziecka i stymulacji językowej w wypowiedziach dzieci zwiększa się jakość i ilość konstrukcji złożonych ${ }^{8}$. Budowanie narracji zostało

nauki języka obcego jest zdolność transferowania operacji mentalnych, służących rozumieniu i produkcji wypowiedzi w innych kontekstach ich użycia. W tym znaczeniu strategie metapoznawcze mają na celu zdystansowanie się do obserwowanych zjawisk, ich ocenę, a w rezultacie antycypowanie przyszłych wypowiedzi (por. przykłady zastosowania takiego podejścia w Karpińska-Szaj i Paprocka-Piotrowska, 2014).

7 « La complexité linguistique de 6 à 14 ans. Acquisition, production, traitement » jest zadaniem badawczym grupy Sens Texte Informatique Histoire koordynowanym przez prof. Claire Martinot z Uniwersytetu Paris Sorbonne. Ze strony polskiej partnerami w projekcie są prof. Urszula Paprocka-Piotrowska (Katolicki Uniwersytet Lubelski) oraz prof. Katarzyna Karpińska-Szaj i dr Bernadeta Wojciechowska (Uniwersytet im. Adama Mickiewicza w Poznaniu). Celem projektu jest zebranie korpusu językowego dzieci w różnych przedziałach wiekowych i określenie na jego podstawie potencjału językowego umożliwiającego produkcję wypowiedzi ustnej na podstawie odsłuchanego tekstu narracyjnego. W aspekcie porównawczym wybranych języków (chorwackiego, francuskiego, polskiego, niemieckiego, włoskiego) projekt ma na celu wyłonienie jednostek językowych stwarzających trudności w formułowaniu wypowiedzi (np. czasowniki wieloznaczne, zdania podrzędnie złożone, zaimki względne itd.). Dla celów realizacji projektu zebrano korpus dzieci bez zaburzeń językowych, a w niniejszym artykule posłużono się wypowiedziami dzieci z deficytami języka i mowy uczęszczającymi do szkół ogólnodostępnych na terenie Poznania, w których przeprowadzono badanie.

${ }^{8}$ Uogólniając wnioski z analizy statystycznej korpusów językowych dzieci uzyskanych w różnych językach (odpowiednio do krajów uczestniczących w projekcie) można stwierdzić, że przetwarzanie danych językowych przez dzieci przebiega od budowania 
Przygotowanie do pracy z uczniami o specjalnych potrzebach edukacyjnych...

też uznane za podstawowe zachowanie językowe świadczące o wykształconych umiejętnościach poznawczych, których rytm w przypadku dzieci o niezaburzonym rozwoju przebiega zgodnie z dojrzewaniem poznawczym i interakcją z otoczeniem (stymulacją środowiska), a w sytuacji dzieci z deficytami języka i mowy powinno być zawsze oszacowane w indywidualny sposób.

W przeprowadzonym doświadczeniu założono, że narracja prowadzona przez dziecko może ujawnić specyficzne trudności dotyczące komunikacyjnej i reprezentatywnej funkcji języka uchwytne dla nauczyciela i dla samego dziecka w prowadzonym następnie dialogu dydaktycznym. W zakresie kompetencji językowo-komunikacyjnych podstawowym celem diagnostycznym, ale też prognostycznym (istotnym dla rozwoju kompetencji w języku obcym) było zbadanie czy dziecko dysponuje środkami językowymi, by wyrazić uchwycone informacje. W zakresie kompetencji poznawczych, celem było wstępne zidentyfikowanie deficytów pojęciowych, które uniemożliwiają przeformułowanie opowiadania z zachowaniem znaczenia. Zdarza się, że dzieci z niedoborami języka pierwszego, mimo ubogiego repertuaru środków językowych nie używają strategii przeformułowania typowych dla młodszych dzieci o prawidłowym rozwoju (np. powtórzeń, zmiany znaczenia), lecz używają strategii logicznych charakterystycznych dla dzieci starszych. W takich przypadkach deficyty językowe wynikają nie tyle z opóźnienia przyswajania kompetencji językowych, lecz ich nieharmonijnego rozwoju ${ }^{9}$.

W wypowiedziach dzieci wzięto zatem pod uwagę:

- obecność i jakość środków językowych świadczących o spójności tekstu (sposoby wprowadzania kolejnych sekwencji, zależność czasową wydarzeń, wyrażanie przyczynowości itd.);

- zgodność odtworzonego tekstu z tekstem oryginalnym (stopień zrozumienia tekstu oraz sposoby kompensowania nieuchwyconych informacji: znajomość schematu narracyjnego, dodawanie elementów treściowych, synteza informacji, wyjaśnianie).

konstrukcji uproszczających formę i treść (powtórzenia z redukcją danych) do użycia konstrukcji coraz bardziej złożonych z zachowaniem znaczenia pierwotnego wypowiedzi (zob. Martinom, 2012; Martinot i in., 2012).

${ }^{9}$ W wypowiedziach młodszych dzieci zdarzają się powtórzenia fragmentów tekstu, które nie zawsze świadczą o ich zrozumieniu, lecz o zapamiętaniu wyróżniającej się jednostki leksykalnej (np. słowo dźwiękowo przyciągające uwagę, wcześniej zasłyszane i skojarzone w danym kontekście). Tej strategii nie można zaobserwować w wypowiedziach dzieci z niedoborami językowymi, zwłaszcza uczniów z głębokimi uszkodzeniami słuchu. Przeformułowanie dotyczy zrozumianych fragmentów lub/i własnych skojarzeń, jednak sama procedura przeformułowania może być bogatsza, charakterystyczna dla starszych dzieci bez deficytów językowych (wnioskowanie, definiowanie, wyjaśnianie). 
Autorami wszystkich prezentowanych poniżej wypowiedzi są uczniowie z głębokimi uszkodzeniami słuchu szóstej klasy ogólnodostępnej szkoły podstawowej Michał, Aleksandra i Igor (12 lat) ${ }^{10}$. Dzieci są rehabilitowane w kierunku rozwoju języka fonicznego, uczą się również języka angielskiego jako obcego od pierwszej klasy szkoły podstawowej. Michał od trzech lat uczy się także dodatkowo języka francuskiego. Doświadczenie przebiegło zgodnie z zasadami komunikacji z uczniem niesłyszącym: spotkania indywidualne, umożliwienie czytania z ust i powtórzeń na żądanie. Prezentowane wypowiedzi zostały sporządzone pisemnie i są cytowane z zachowaniem oryginalnej pisowni dzieci.

(1) Ta pani, która trzymała rękę dziewczynce weszła do szkoły. Pani opowiadała dzieci w całej klasie, że mamy nowq koleżankę Julkę i chciała żeby wszyscy były dla niej mili i mówiła Julce, że tu jest dla niej wolne krzesło i poprosiła kolegę żeby był dla niej mity żeby dużo sobie pogadali. Tomek się cieszył, że ma nowq koleżankę i wieczorem w domu dał jej prezent, tylko przygotował sobie złote pudełko. Tomek następnego dnia poszedł do Julki i chciał podać złote pudełko i Julce tak się bardzo mu podobało. Pani powiedziała, żeby wyjęli książki czyli podręczniki do szkoły. Julka pudetko była na ławce pomiędzy Tomkiem. Julka wyszła do Tomka i napisała na kartce, że się spotykamy o godzinie 20 wieczorem. Julka wychodziła do Tomka po cichu spotykaja się w lesie pod wielkim drzewem i Tomek się bał ponieważ nie wolno było chodzić do lasu, bo tam nie wolno było chodzić. Jak już była 20 wieczorem Julka cały czas czekała na Tomka. Potem Julka weszła za rękę Tomka i trzy razy puknęła w drzewo i drzewo po kilku minutach po cichu się obracało przez siebie. I dopiero potem drzewo zamknęło się za siebie i najpierw się otworzyło było światło. Teraz drzewo się otworzyło i Tomek i Julka poszli do środka i tam był przepiękny ogród i można rozmawiać z roślinami. Julka powiedziała "chodź jest przepiękny ogród, jest król i reszta zwierzqt można króla poprosić o rozmowę.." W ogrodzie też było jezioro. Tomek chciał się nauczyć w rozmowie z królami, to znaczy z mrówkami to znaczy z rybkami, on musi wiedzieć wszystko co się dzieje na ziemi i w wodzie. To znaczy Tomek chciał w powietrzu porozmawiać z ptakami i następnego dnia Tomek stał się bardzo mądrym chłopakiem. (Michał)

W wypowiedzi Michała zostały zachowane wszystkie elementy istotne dla przebiegu opowiadania. Charakterystyczne są liczne sekwencje wyjaśniające wprowadzane za pomocą "to znaczy". Z dialogu dydaktycznego przeprowadzonego $z$ dzieckiem wynika, że w ten sposób chłopiec kontroluje własne rozumienie, upewnia się, że jego wypowiedź jest spójna („Ja wiem co to znaczy, ale boję się nie pamiętać co jest dalej"). Chłopiec zrozumiał opowiadanie, ale zabrakło mu środków językowych, by wyrazić spójność tekstu. Szczególną

${ }^{10}$ Imiona dzieci zostały zmienione. 
Przygotowanie do pracy z uczniami o specjalnych potrzebach edukacyjnych...

trudność stanowiło wyrażenie przyczynowości, chociaż została ona uchwycona i wyrażona w opowiadaniu następstwem czasowym.

(2) Pewnego dnia do szkoły przyszła nowa dziewczynka Julka. Pani trzymała ja za rękę i przedstawiła klasie. Ona usiadła obok Tomka, bo tam było wolne miejsce. Chłopak pomyślat, że będzie miał nowq przyjaciółkę i był tak zadowolony, że zrobił dla niej małe pudetko, które jej się tak podobało, że nosiła je zawsze przy sobie. Pewnego dnia pani poprosiła o wyjęcie swoich rzeczy. Julka położyła pudełko tam gdzie zawsze i powiedziała do Tomka „otwórz". Była tam kartka z napisem: "spotkamy się przy wejściu do lasu przy biatym drzewie o 8". Mimo że Tomek nie lubi chodzić nocq, a zwłaszcza po lesie jednak postanowił przyjść na spotkanie. Gdy przyszedł podeszli do drzewa i Julka zapukała trzy razy idrzewo przepołowiło się a w pniu pojawiło się białe światło, do którego weszli. Julia powiedziała: „jeśli masz jakqśs prośbę poproś naszego króla". Tomek poprosit o rozmawianie z ptakami i od tamtej pory był madrym dzieckiem. (Aleksandra)

Aleksandra wykazała się bardzo dobrą zdolnością selekcji i syntezy informacji. W odsłuchanym tekście potrafiła wyodrębnić informacje najistotniejsze dla przebiegu narracji oraz przedstawić je w zdaniach złożonych. W dialogu dydaktycznym potrafiła uzasadnić wszystkie dopowiedziane elementy, które jej zdaniem potrzebne były do uzasadnienia wywodu („Ona usiadła obok Tomka, bo tam było wolne miejsce”, „Chłopak pomyślał, że będzie miał nową przyjaciółkę i był tak zadowolony, że zrobił dla niej małe pudełko..."). Większość przeformułowań ma charakter logiczny. Chcąc uniknąć powtórzeń, uczennica stosuje w wielu miejscach zamienniki leksykalne. Widoczne są także przeformułowania formalne o wyższym stopniu złożoności niż w tekście źródłowym („pani poprosiła o wyjęcie...", „Tomek poprosił o rozmawianie...”).

(3) Był taki dzień, kiedy pani trzymała dziewczynkę za rękę którq nikt niej nie widział. Pan powiedział, że obok Tomka jest pusto. Tomek chciał, aby Julka była go koledzanka. Tomek zrobił jej szynkę. I od tego mentu zostali przyjacielami. Jednego razu Julka powiedziała otwórz szynkę. Tomek otworzył. Było napisane; spotkajmy się obok lasu w nocy. Się spotkali. Julka zapukała kilka razy w drzewie. Otworzył się i były jasne światło. Julka powiedziała przez cała noc król spełni twoje życzenia. Tomek powiedział królowi, że chce rozmawiać z ptakami i z mrówkami. Od tej pory Tomek jest mqqdry. (Igor)

W pracy Igora widoczne są błędy ortograficzne (np. ujednolicenie w odbiorze i w konsekwencji w zapisie głosek syczących: „koledzanka” (koleżanka), "szynka” (skrzynka) i gramatyczne (np. błędne konstrukcje: „pukała w drzewie”, "Julka była go koledzanka”, „zostali przyjacielami”, ,były jasne światło”). W wypowiedzi zachowano część szczegółów istotnych dla przebiegu opowiadania 
(np. motyw króla spełniającego życzenia), przytoczono także elementy drugorzędne, które w wypowiedzi ucznia są mocno zaakcentowane (np. „pani trzymała za rękę dziewczynkę").

Uzyskany korpus ukazał różnorodność problemów związanych z tworzeniem wypowiedzi pisemnych na podstawie odsłuchanego opowiadania, pomimo tej samej przyczyny trudności w przyswajaniu języka ojczystego (głęboki niedosłuch prelingwalny). Przykłady wypowiedzi dzieci świadczą o tym, że indywidualny program nauczania dzieci niesłyszących zarówno w zakresie języka polskiego jak i języków obcych nie może być oparty na tych samych przesłankach, mimo tego samego stopnia uszkodzenia słuchu i podobnego doświadczenia w rehabilitacji. Dialog dydaktyczny towarzyszący analizie wypowiedzi dzieci umożliwił uświadomienie przyczyn trudności językowych w przypadku Michała, a w przypadku Igora specyfiki trudności pojęciowych (kłopoty ze zrozumieniem i zachowaniem spójności narracji powodowane brakiem selekcji najistotniejszych informacji zawartych w tekście).

Uzyskany korpus językowy, na podstawie którego przeprowadzono dialog dydaktyczny z dziećmi stanowi komponent diagnozy na potrzeby rehabilitacji językowej. Może on być realizowany także w trakcie nauki języka obcego dzięki stworzeniu podwalin do rozwijania strategii uczenia się, jaką jest umiejętność obserwacji zjawisk językowych i transferowania swych umiejętności i wiedzy na sytuacje komunikacyjne w obu językach. Doświadczenie zostało zrealizowane na początku roku szkolnego, co umożliwiło także modyfikację IPETu pod kątem dostosowania celów i przebiegu nauczania języka angielskiego jako obcego do potencjału rozwojowego uczniów. O ile w przypadku Aleksandry chodziło przede wszystkim o dostosowanie materiałów dydaktycznych pod względem dostępności percepcyjnej oraz organizację pracy własnej i kryteriów oceny postępów (wydłużenie czasu realizacji prac kontrolnych, odpowiednie sformułowanie poleceń), to w przypadku Michała i Igora uzupełniono cele terapeutyczne o pracę porównawczą w zakresie języka polskiego i angielskiego (m.in. sposoby wyrażania przyczynowości w obu językach, zasady budowania wypowiedzi pisemnej, respektowane schematu narracji).

\section{Podsumowanie}

W sytuacji deficytów języka i mowy, rozwój językowych kompetencji komunikacyjnych może następować w sposób niepełny, odpowiednio do właściwych danemu uczniowi możliwości poznawczych i obranych celów nauki. Zdolność kontrolowania swoich wypowiedzi, używanych strategii komunikacyjnych zwiększa potencjał nauki języka obcego. Jest ona bowiem wykorzystania nie tylko do rozwijania kompetencji w języku obcym, ale do podnoszenia kompetencji w języku ojczystym. 
Umiejętność wykorzystania nauki języka obcego do konfrontowania analogicznych zjawisk w języku ojczystym, świadomość indywidualnych cech poznawczych sprzyjających tworzeniu reprezentacji przyswajanych treści i rozwijaniu określonych kompetencji nie pojawia się jednak spontanicznie. Nauka języka obcego nie zmniejszy trudności i nie zmieni specjalnych potrzeb uczniów z deficytami języka i mowy. Jednak specyfika obserwowanych trudności wynika nie tylko z rodzaju deficytów, ale także możliwości ich kompensowania, a te mogą być systematycznie doskonalone w trakcie nauki języka obcego i przekładać się poziom ogólnych kompetencji językowych.

Użycie przeformułowania zarówno w celach diagnostycznych w języku polskim jak i w ćwiczeniach na lekcji języka obcego może stać się strategią uczenia się posiadającą dużą wartość rehabilitacyjną. Wynika ona z funkcji informacyjnej przeformułowania (oszacowanie ewentualnych niedoborów językowych i komunikacyjnych), ale także z możliwości kompensowania pojawiających się trudności poprzez uświadomienie ich specyfiki. Dzieje się tak poprzez wykorzystanie sytuacji uczenia się nowego języka jako naturalnego powrotu do wcześniejszych etapów przyswajania/uczenia się języka polskiego.

\section{BIBLIOGRAFIA}

Béguin, Ch. 2008. « Les stratégies d'apprentissage : un cadre de référence simplifié ». Revue des sciences de l'éducation 34(1): 47-67.

Czaplewska, E., Milewski, S. (red.). 2012. Diagnoza logopedyczna. Podręcznik akademicki. Sopot: Gdańskie Wydawnictwo Psychologiczne.

Gunia, G. 2006. Terapia logopedyczna dzieci z zaburzeniami słuchu i mowy. Wybrane problemy teorii i praktyki surdologopedycznej. Kraków: Oficyna Wydawnicza Impuls.

Karpińska-Szaj, K. 2013. Nauczanie języków obcych uczniów z niepełnosprawnościq w szkołach ogólnodostępnych. Poznań: Wydawnictwo Naukowe UAM.

Karpińska-Szaj, K., Paprocka-Piotrowska, U. 2014. « La reformulation en tant que stratégie d'apprentissage d'une LE: vers son exploitation dans des situations nonordinaires ». Roczniki Humanistyczne LXII/10 Glottodydaktyka: 55-82.

Krakowiak, K. 2006. „Pedagogiczna typologia uszkodzeń słuchu i osób nimi dotkniętych” (w) "Nie głos, ale słowo...". Przekraczanie barier w wychowaniu osób z uszkodzeniami słuchu. (red. K. Krakowiak i A. Dziurda-Multan). Lublin: Wydawnictwo KUL: 255-288.

Martinot, C. 2012. " De la reformulation en langue naturelle, vers son exploitation pédagogique en langue étrangère: pour une optimisation des stratégies d'apprentissage " (w) Autour de la compétence d'apprentissage de langues: gestion des ressources métacognitives et cognitives. (red. K. Karpińska-Szaj, J. Zając). Synergies-Pologne 9: 63-76.

Martinot, C., Gerolimich, S., Bosniak-Botica, T., Tutunjiu, E. 2012. « Un phénomène complexe d'acquisition en langue maternelle: le cas des relatives dans une 
perspective translinguistique » (w) La complexité en langue et son acquisition (red. U. Paprocka-Piotrowska, C. Martinot, S. Gerolimich). Lublin: Towarzystwo Naukowe KUL: 169-212.

Podstawa Programowa z komentarzami. T. 3. 2009: Języki obce w szkole podstawowej, gimnazjum, liceum zasoby internetowe: http://www.lingwistyka.edu.pl /upload/materialy/167_podstawa_programowa_z_komentarzem_tom_3.pdf DW 20.08.2014. 


\section{Załącznik: \\ Tomek i Julka (tekst źródłowy z podziałem na sekwencje)}

1. Tego ranka Pani weszła na szkolne podwórko później niż zwykle. Trzymała za rękę dziewczynkę, której nikt dotąd nie widział.

2. Gdy już weszli do sali Pani powiedziała „Dzieci, przedstawiam wam nową koleżankę, ma na imię Julka. Tomku, miejsce obok ciebie jest wolne, Julka będzie siedzieć obok ciebie, bądź dla niej miły!".

3. Tomek bardzo się cieszył, że być może będzie miał nową koleżankę. Wieczorem w domu zrobił dla Julki okrągłe złoto-czerwone pudełeczko.

4. Nazajutrz rankiem, na szkolnym podwórku Tomek niecierpliwie wyglądał przybycia swojej nowej sąsiadki. Gdy tylko ją spostrzegł, podbiegł do niej i dał jej pudełko, które zrobił dla niej poprzedniego wieczoru.

5. Julce tak się to pudełeczko spodobało, że wszędzie je ze sobą zabierała. A kiedy pani mówiła „wyjmijcie swoje rzeczy”, Julka delikatnie kładła pudełeczko na ławce, pomiędzy nią i Tomkiem.

6. Pewnego dnia Julka szepnęła do Tomka „otwórz pudełko!”. Tomek podniósł pokrywkę i zobaczył karteczkę, na której Julka napisała „Czekam na Ciebie dziś wieczorem o 8.00 pod wielkim drzewem przy wejściu do lasu”.

7. Tomek trochę się bał, zwłaszcza, że nie wolno mu było chodzić do lasu, a już zwłaszcza nocą.

8. Jednak o 8.00 stawił się na spotkanie, Julka już na niego czekała.

9. Bez słowa dziewczynka wzięła Tomka za rękę i trzy razy zastukała w pień wielkiego drzewa.

10. Po kilku minutach dzieci usłyszały jakieś skrzypienie. To drzewo obracało się wokół siebie.

11. Nagle pień drzewa otworzył się a dzieci olśniło światło wydobywające się z wnętrza drzewa. Gdy zrobili kilka kroków, drzewo zamknęło się za nimi.

12. Tomek i Julka znaleźli się w cudownym ogrodzie, gdzie wydawało się, że kwiaty rozmawiają ze sobą śpiewając. Wtedy Julka powiedziała do Tomka „Chodź, przejdźmy przez ogród, dziś wieczór jest przyjęcie na twoją cześć. Aż do północy możesz prosić naszego króla o co chcesz".

13. Tomek odpowiedział „Chcę nauczyć się rozmawiać z ptakami, które wiedzą o wszystkim co się dzieje w niebie, z rybami, które wiedzą o wszystkim co się dzieje w wodzie i z mrówkami, które wiedzą o wszystkim co się dzieje na ziemi".

14. I od tego dnia, Tomek stał się bardzo mądrym dzieckiem. 